\title{
Lakunární ischemický iktus
}

MUDr. Linda Kašičková', MUDr. Pavel Ressner, Ph.D., ${ }^{1,2}$, doc. MUDr. Michal Bar, Ph.D., ${ }^{1,2}$

'Neurologická klinika, Fakultní nemocnice Ostrava

¿2ékařská fakulta, Ostravská univerzita v Ostravě

Obr. 1. Jádra levého thalamu (Wells, 1983)

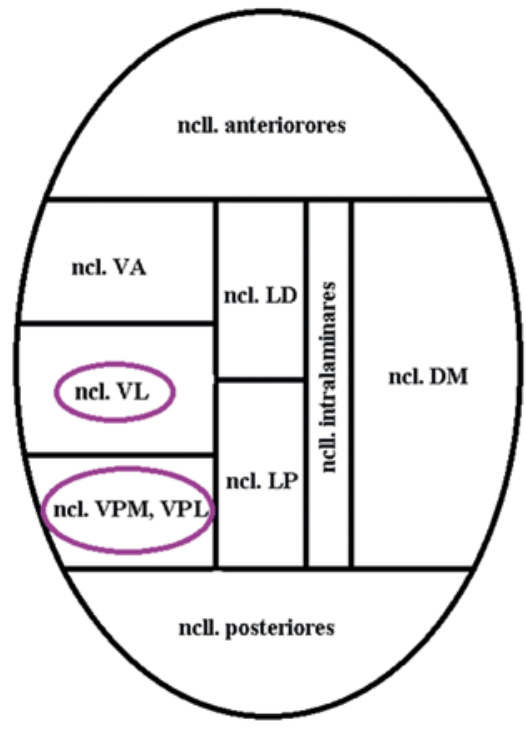

Pacientka, narozená v roce 1954, přijata akutně pro čtyři dny trvající trnutí levé poloviny těla včetně obličeje, pocit nestability při chůzi a slabosti levostranných končetin. Objektivně v neurologickém nálezu lehká, postupně regredující, levostranná ataktická centrální hemiparéza. Vstupně bylo provedeno nativní CT mozku s nálezem počínající korové atrofie a drobných starších poischemických změn bilaterálně v bazálních gangliích, bez známek čerstvé ischemie či krvácení. (Na EEG normální záznam. Neurosonologicky pouze drobné aterosklerotické pláty v karotické bifurkaci, normální toky na zobrazených cévách, TCCS: RI ACM I dx. 0,66;
Obr. 2. Hyperintenzní ložisko v T2 vážené sekvenci v pravém thalamu

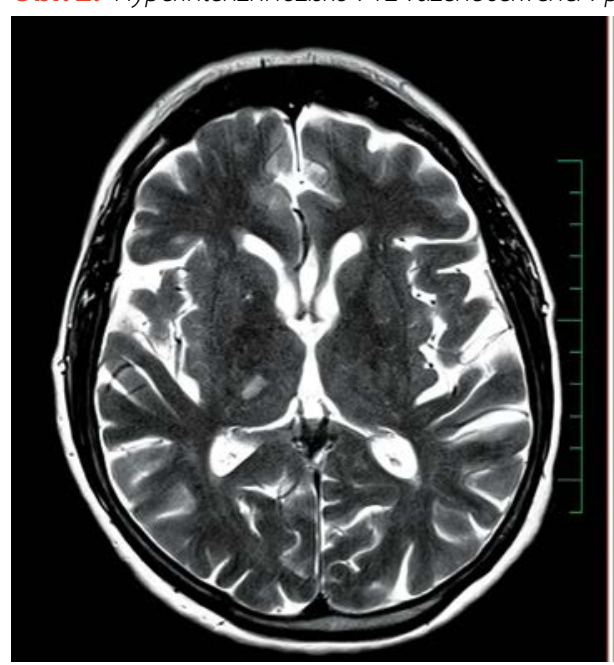

ACM I. sin 0,61.) Doplněno MRI mozku, kde nález ischemické léze $10 \times 8 \mathrm{~mm}$ dorsálně na rozhraní capsula interna a thalamu vpravo s dokončenou restrikcí na DWI. Anatomická lokalizace ischemické léze odpovídá lokalizaci 2 specifickým (senzorickým) a 1 motorickému jádru thalamu. Nucleus ventralis posteromedialis (ncl. VPM) přijímá somatosenzorické a senzorické informace z inervační zóny nervus trigeminus cestou lemniscus trigeminalis a tractus trigeminothalamicus. Nucleus ventralis posterolateralis (ncl. VPL) přijímá somatosenzotické informace cestou lemniscus medialis a tractus trigemoinothalamus z trupu a končetin. Nucleus ventralis (ncl. VL) je specifické motorické jádro přijímající informace z mozečku, jehož poškozením Ize vysvětlit ataxii kontralaterálních končetin, přičemž samotná ataxie je vysvětlitelná

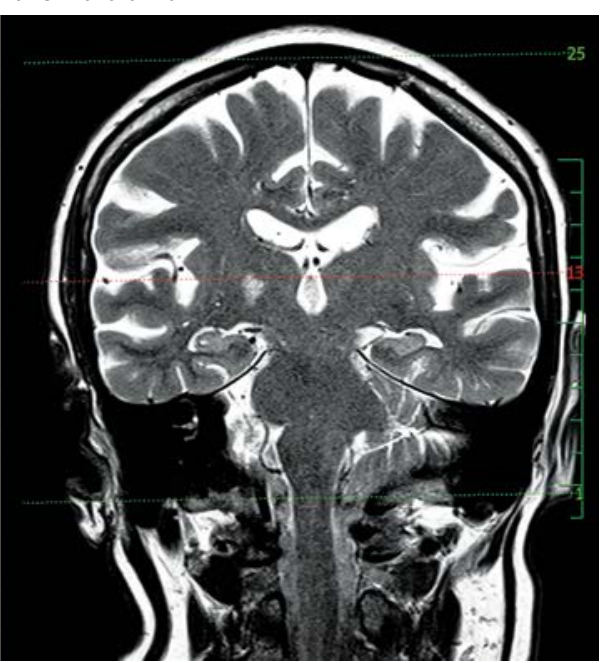

Obr. 3. Hyperintenzní ložisko ve FLAIR sekvenci v pravém thalamu

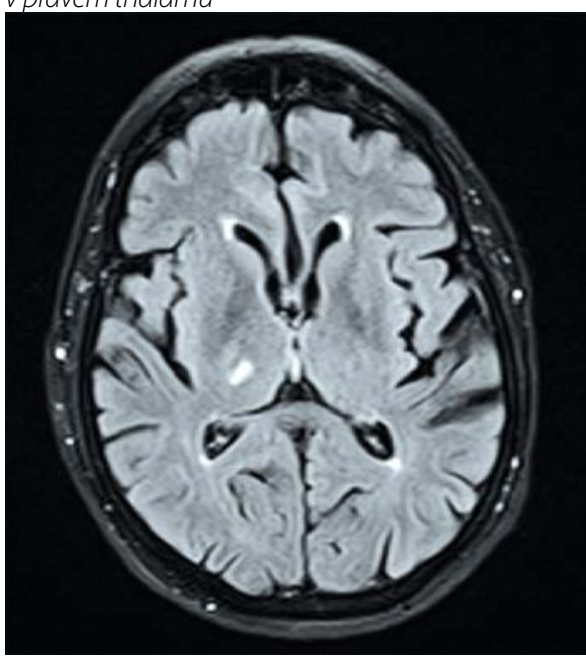

i prítomností centrální hemiparézy. Příčinou iktu byla mikroangiopatie. V rámci sekundární prevence byla pacientka zajištěna antiagregací.

\section{LITERATURA}

1. Wells J. Human neuroanatomy, $8^{\text {th }}$ edition. Edited by W. B. Carpenter, J. Sutin, 872 pp, Williams \& Wilkins, Baltimore, MD, 1983. Muscle Nerve, 1983; 6: 462 